\title{
Oral cancer in Brazil: a secular history of Public Health Policies
}

\author{
Prevenção e controle do câncer bucal no Brasil: uma história secular de Políticas Públicas de Saúde
}

Paulo Ricardo Saquete MARTINS FILHO'

Thiago de Santana SANTOS ${ }^{2}$

Luiz Carlos Ferreira da SILVA ${ }^{3}$

Marta Rabello PIVA ${ }^{3}$

\begin{abstract}
The oral cancer in Brazil is considered an important public health issue. Despite almost a century of combat disease, with oncological assistance programs and prevention campaigns based public policies, the incidence of oral cancer in several regions is still high. The major goal of cancer prevention and control is a reduction in both the incidence of the disease and the associated morbidity and mortality, as well as improved life for cancer patients and their families. Low-income and disadvantage groups are generally more exposed to avoidable risk factors such as tobacco and alcohol consumption. These groups have less access to the health services and education that would empower them to make decisions to protect and improve their own health. Thus, cancer control programs are the most effective instrument to bridge the gap between knowledge and practice and achieve this goal. The authors report some key historical facts concerning the fight against oral cancer in Brazil, in addition to addressing the epidemiological aspects of disease.
\end{abstract}

Indexing terms: Health policy. Mouth neoplasms. Public health.

\section{RESUMO}

O câncer de boca no Brasil é considerado um importante problema de saúde pública. Apesar de quase um século de combate à doença, com políticas públicas baseadas em programas de assistência oncológica e campanhas de prevenção, ainda é alta a incidência do câncer de boca em diversas regiões do país. O objetivo principal da prevenção e controle do câncer é a redução na incidência da doença, como também, da morbidade e mortalidade associadas, além da melhoria da qualidade de vida para pacientes e suas famílias. Populações com baixa renda e grupos desfavorecidos são geralmente mais expostos a fatores de risco evitáveis, como o tabaco e o consumo de álcool. Estes grupos têm menos acesso aos serviços de saúde e educação que lhes permitam tomar decisões para proteger e melhorar a sua própria saúde. Assim, os programas de controle do câncer são o instrumento mais eficaz para diminuir a distância entre conhecimento e prática e alcançar esta meta. Os autores relatam alguns dos principais fatos históricos relativos à luta contra o câncer de boca no Brasil, além de abordar aspectos epidemiológicos da doença.

Termos de indexação: Política de saúde. Neoplasias bucais. Saúde pública.

\section{INTRODUCTION}

Cancer is a major public health problem in developed and developing countries, accounting more than 10 million new cases and more than 6 million deaths each year worldwide 1 . Oral cancer is significant component of the global burden of cancer and has a higher prevalence in North America, Central and Eastern Europe, India, South and Eastern Africa, Australia and Brazil2.

The major goal of cancer prevention and control is a reduction in both the incidence of the disease and the associated morbidity and mortality, as well as improved life for cancer patients and their families. Low-income and disadvantage groups are generally more exposed to avoidable risk factors such as tobacco and alcohol consumption. These groups have less access to the health services and education that would empower them to make decisions to protect and improve their own health. Thus, cancer control programs are the most effective instrument to bridge the gap between knowledge and practice and achieve this goal ${ }^{2}$.

In Brazil, since the beginning of the $20^{\text {st }}$ century, has been trying to introduce public policies to combat oral cancer. Despite the efforts, still are noted high rates of prevalence of oral malignant tumors, in individuals of different ages, gender and regions. Conditions observed among this Brazilian population were essentially the same as those that have been described in other populations around the world. Different factors increased the probability of specific oral mucosal

\footnotetext{
${ }^{1}$ Universidade Federal de Sergipe, Centro de Ciências Biológicas e da Saúde, Programa de Pós-Graduação em Odontologia. Rua Cláudio Batista, s/n., Santo Antônio, 49060108, Aracaju, SE, Brasil. Correspondência para / Correspondence to: PRS MARTINS FILHO. E-mail: <saqmartins@yahoo.com.br>

${ }^{2}$ Universidade de Pernambuco, Faculdade de Odontologia. Recife, PE, Brasil.

${ }^{3}$ Universidade Federal de Sergipe, Centro de Ciências Biológicas e da Saúde, Departamento de Odontologia. Aracaju, SE, Brasil.
} 
conditions $^{3}$. The aim of this paper is to discuss about the main historical facts concerning the secular fight against oral cancer in Brazil, in addition to addressing the epidemiological aspects of disease.

\section{DISCUSSION}

The effective combat against cancer in Brazil dates from the early $20^{\text {th }}$ century, when endemic diseases, as yellow fever, smallpox, Chagas disease and malaria, occupied the attention of public policies through "hygienist movement" led by Oswaldo Cruz and Carlos Chagas ${ }^{4}$. At this time, in the Europa and United States, cancer began to appear between diseases of higher mortality rates, forcing the Brazilian government to include proposals for a policy to combat cancer in the national health legislation. In 1921, there was creation of the National Cancer Department, with the purpose to establish statistics about the disease, especially through the reporting of cases and especial printed on death certificates ${ }^{5}$.

In September 1922, during National Practitioners' Congress, in Rio de Janeiro State, the obstetrician Fernando de Magalhães defined cancer as a "universal evil" and reported the sudden increase in the incidence of disease in national territory based on compulsory notification imposed by sanitary reform at the beginning of the decade. From there, it was introduced the first national anticancer plain through state action with the medical elite. One of the measures adopted was the application of resources for the construction of establishments for patients with leprosy, venereal diseases and cancer ${ }^{6}$.

Some descriptions of oral malignant tumors also began to be made in the 1920s, at the Santa Casa de Misericórdia, Rio de Janeiro State, through newsletter about the clinical condition of patients before surgery and the procedures undertaken for the removal of lesions. A revolution in surgical techniques was the introduction of electric cautery to remove tumors, brought by Dr. Mário Kroeff to the Santa Casa de Misericórdia after serving in World War I thought the Brazilian Military Medical Mission as $1^{\text {st }}$ Lieu Tenant ${ }^{7}$.

A significant advance in the care of patients with malignant tumors occurred in 1937 through Decree Law $n$. 378 signed by President Getúlio Vargas, which culminated in the creation of the Oncology Center, in Rio de Janeiro State, for prophylaxis and cancer treatment ${ }^{8}$. Oncology Center was the birthplace of the National Cancer Institute (INCA) and had as its founding director, Professor Mário Kroeff. At this time, Mário Kroeff started a work of awareness among surgeons and dentists in early detection of oral cancer.

In 1939, an interesting report in Oncology Center was made during the procedure to remove a tumor in the oral cavity:

\begin{abstract}
"O aparelho de eletrotórmia entra em funcionamento sob o olhar curioso de todos. Os fotógrafos se preparam. E na boca do paciente, senhor U.G.P. inicia-se um quadro bem desagradável para os que não estão acostumados a este procedimento cirúrgico: queimam-se a eletricidade irradiada as gengivas cancerosas; dentes rolam pela boca em meio de pedaços de carne necrosada. E o fotógrafo de um vespertino dá sinal evidente de que o espetáculo está além de sua sensibilidade, e é retirado da sala por um repórter mais resistente" 7 .
\end{abstract}

In 1941, the National Cancer Service was created, in Rio de Janeiro State, whose responsibility was also granted to Professor Mário Kroeff and had as main objectives the organization, direction and control of national prevention campaign of cancer. In 1944, the Oncology Center has become in Cancer Institute and was then transformed in executive department of Cancer National Service. For policy issues, the Cancer Institute ran, until 1957, in the dependencies of Graffré and Guinle Hospital, period in which it was inaugurated by the President Juscelino Kubitschek. It is interesting to comment that during this phase of implementation of national policy to combat the cancer, the epidemiological aspects of disease began to be seen with the analysis of environmental conditions, territorial extension and the contrasts of the country. Similarly, especial attention began to be given to preventive aspects and early diagnosis of the disease ${ }^{9}$.

In 1947, Alberto Coutinho, first director of National Cancer Institute, proposed the establishment of oncology regular teaching in medicine faculties through law project to the National Congress. At the time, Alberto Coutinho had already established in the Dentistry National School, Rio de Janeiro State, the "annual courses of oral cancer and related diseases". Only in the 60s, there was an effective political effort to implement a program of oncology teaching in universities and public colleges ${ }^{9}$.

In the 1950s, dentistry was included as specialty in the Cancer National Service and in 1960s head and neck surgery was recognized as specialty. In 1967, the National Campaign to Cancer's Combat was created and had as one of its main objectives to encourage 
the establishment of population-based cancer records in different regions of the country. However, only in the $80 \mathrm{~s}$ and with the creation of the Unified National Health System (SUS) an effective national policy to combat cancer has been established, when the Ministry of Health, under the National Campaign to Cancer's Combat, began to develop decentralized actions in the information area (cancer records), prevention of risk factors and oncology education ${ }^{10}$.

Despite the advances, cancer still continued to be considered an individual problem, with interruption of national policies to combat the disease. In the early 70s, the National Cancer Service was extinct and was created the National Cancer Division linked to the Ministry of Health, which would elaborate in 1976 the National Program for Prevention and Early Diagnosis of Oral Cancer (CABUL). This program sought to mobilize articulated measures of national scope to combat oral cancer ${ }^{11}$.

In 1986, the National Campaign to Cancer's Combat and INAMPS created the Pro-Onco (Coordination Program for the Cancer Control), based in Rio de Janeiro State, establishing oral cancer as priority of the public health because the disease affects an area of the body that is easy to access for clinical inspection. The intention was an immediate intervention from 1988 to 1993. Thus, in 1987, the Expansion Program of Prevention and Oral Cancer Control was established, aiming to reduce the morbimortality indices for oral cancer, in the five years cited, seeking to integrate the various sectors involved in the issue of prevention and control of this neoplasia ${ }^{12}$.

According Teles ${ }^{13}$, the data relating to oral cancer on national territory, until the 1980s, do not reflect the real situation of the problem, since such data were based on reports submitted by service centers of pathological anatomy that not covered most dental faculties. Saltz ${ }^{11}$ reported that, in this period, were notified to the National Register of Tumoral Pathology about 13.000 histopathological diagnosis of oral cancer in Brazil, where of this total $56 \%$ were reported by hospitals of cancer, $19 \%$ by faculties of medicine and only $2.3 \%$ by faculties of dentistry.

The aid to the exchange between institutions, oncology services and people working on records of cancer occurred only in 1992 with the creation of the Brazilian Association of Cancer Registries. In 1995, the first hospital cancer registry was created, through INCA. In 1998, population parameters were being used by the estimate of new cases reporting by region. In turn, the population parameters for defining the need for procedures and services developed under the Expansion Project of Oncology Assistance, implemented in conjunction with the State and Municipal Secretariats of Health and in accordance with the principles of the SUS ${ }^{14}$.

Currently, INCA is responsible for formulating national policy for prevention and control of cancer. Besides the training of physicians specializing in several areas of oncological practice, the INCA coordinates and develops actions in five strategic areas for the control of cancer, which are the (1) prevention; (2) medicohospital assistance; (3) research; (4) education and; (5) epidemiological information ${ }^{15}$.

Since the establishment of the Oncology Center, a health policy to combat cancer based on preventive actions and care was devised in an attempt to correct the trend, which also occurred in Brazil, to prioritize the individual therapies actions. Nowadays, special attention has been given to the campaigns of mass awareness about the risk factors and the signs and symptoms related to oral cancer, providing increased individual surveillance in relation to prevention and early diagnosis of disease ${ }^{16}$. In 2005, the Ministry of Health conducted a national campaign to encourage the practice of oral self-examination, know as "Self-Examination Campaign Against Oral Cancer - Smile to Yourself". Since 2004, the Oncocentro Foundation and FOSP perform exams in São Paulo State in order to identify lesions in the oral cavity. Only in 2008, 480.607 individuals were examined and detected 50 cases of oral cancer.

Despite the efforts, a high incidence of oral malignant tumors in several regions of Brazil is still observed. In some institutions, an average of more than 100 cases per year has been recorded (Table 1) ${ }^{17-33}$. It is possible that the language and dimension of programs and campaigns against oral cancer are not ideal when considering the socioeconomic diversity of the country. Dib ${ }^{34}$ analyzed the information degree of different classes of the population about issues related to oral cancer and concluded that there is a large gap of information on specific aspects of prevention and diagnosis of disease, including in relation to the self-examination.

According Abdo et al. ${ }^{35}$, most patients with oral cancer has low income and poor level of education. The illiteracy rate found by these authors in a study of 154 patients of oral squamous cell carcinoma was $44.8 \%$. Similarly, some studies indicated a need to update on the knowledge of the risk factors and diagnosis of oral cancer by brazilian dentists ${ }^{36-37}$. 
Table 1. Prevalence of oral cancer in Brazil.

\begin{tabular}{|c|c|c|c|c|}
\hline State & Author and place & Period & Cases & $\begin{array}{l}\text { Cases/ } \\
\text { Year }\end{array}$ \\
\hline MA & $\begin{array}{l}\text { Coaracy et al.17, Aldenora } \\
\text { Bello Oncological Institute }\end{array}$ & $1992-2004$ & 143 & 11.0 \\
\hline$C E$ & $\begin{array}{l}\text { Osterne et al. }{ }^{18} \text {, Faculty } \\
\text { of Nursing, Dentistry and } \\
\text { Pharmacy - UFC }\end{array}$ & $1997-2005$ & 81 & 9.0 \\
\hline RN & $\begin{array}{l}\text { Costa et al. }{ }^{19}, \text { Dr. Luiz } \\
\text { Antônio Hospital }\end{array}$ & 1973-1998 & 952 & 36.6 \\
\hline PB & $\begin{array}{l}\text { Sampaio et al. }{ }^{20} \text {, Napoleão } \\
\text { Laureano Hospital } \\
\text { Barreto et al. }{ }^{21} \text {, Napoleão } \\
\text { Laureano Hospital }\end{array}$ & $\begin{array}{l}1962-1981 \\
1989-1999\end{array}$ & $\begin{array}{l}1.126 \\
1.237\end{array}$ & $\begin{array}{l}56.3 \\
112.5\end{array}$ \\
\hline$P E$ & $\begin{array}{l}\text { Antunes et al. }{ }^{22} \\
\text { Cancer Hospital } \\
\text { Oswaldo Cruz } \\
\text { University Hospital }\end{array}$ & $1983-2003$ & $\begin{array}{l}590 \\
818\end{array}$ & $\begin{array}{l}29.5 \\
40.9\end{array}$ \\
\hline SE & $\begin{array}{l}\text { Anjos Hora et al. }{ }^{23} \\
\text { Anatomical Pathology } \\
\text { Services }\end{array}$ & 1979-1999 & 1.287 & 61.3 \\
\hline MG & $\begin{array}{l}\text { Gervásio et al. }{ }^{24} \text {, Mário } \\
\text { Penna Hospital and } \\
\text { Luxemburgo Hospital } \\
\text { Daher et al. }{ }^{25} \text {, Dr. Hélio } \\
\text { Angotti Hospital }\end{array}$ & $\begin{array}{l}1986-1996 \\
1999-2003\end{array}$ & $\begin{array}{l}740 \\
101\end{array}$ & $\begin{array}{l}67.3 \\
20.2\end{array}$ \\
\hline SP & $\begin{array}{l}\text { Sobral et al }{ }^{26} \text {, } \text {. Faculty } \\
\text { of Dentistry - São Paulo } \\
\text { University } \\
\text { Fardin et al. }{ }^{27} \text {, Heliopolis } \\
\text { Hospital } \\
\text { Perez et al. }{ }^{28} \text {, Heliopolis } \\
\text { Hospital } \\
\text { Oliveira et al. }{ }^{29} \text {, Clinical } \\
\text { Hospital - Ribeirão Preto } \\
\text { Medical School }\end{array}$ & $\begin{array}{l}1970-1997 \\
1977-1998 \\
2000-2004 \\
1982-2002\end{array}$ & $\begin{array}{l}640 \\
1.440 \\
552 \\
340\end{array}$ & $\begin{array}{c}22.9 \\
65.5 \\
110.4 \\
16.2\end{array}$ \\
\hline PR & $\begin{array}{l}\text { Guembarovstki et al }{ }^{30} \\
\text { Erasto Gaertner Hospital } \\
\text { and Northern Paraná } \\
\text { University Dental Care } \\
\text { Center }\end{array}$ & $2002-2005$ & 91 & 30.3 \\
\hline SC & $\begin{array}{l}\text { Nasser }^{31} \text {, Cipac and BML } \\
\text { Laboratories }\end{array}$ & 1980-1999 & $395^{*}$ & 19.7 \\
\hline RS & $\begin{array}{l}\text { Pithan et al.32, São Lucas } \\
\text { Hospital - PUCRS } \\
\text { Spara et al. }{ }^{33} \text { Santa Maria } \\
\text { University Hospital }\end{array}$ & $\begin{array}{l}1978-2003 \\
1980-2003\end{array}$ & $\begin{array}{l}400 \\
216\end{array}$ & $\begin{array}{l}15.4 \\
9.0\end{array}$ \\
\hline
\end{tabular}

Note: MA: Maranhão; CE: Ceará; RN: Rio Grande do Norte; PB: Paraíba; PE: Pernambuco; SE: Sergipe; MG: Minas Gerais; SP: São Paulo; PR: Paraná; SC: Santa Catarina; RS: Rio Grande do Sul. * Cases of squamous cell carcinoma of the lip.

After several decades, epidemiological studies able to trace the profile of brazilian patients with oral cancer (table 2) 17-30,32-33, with some variations related to lifestyle and region. Examples of these variations are seen in (1) Santa Catarina, which has one of the highest rates of UVB-index in Brazil and is high the incidence of actinic cheilitis and squamous cell carcinoma of the lower lip in Caucasian ${ }^{31,38 ;}$; (2) Paraná and Rio Grande do Sul, where the mate drinking has been associated to oral cavity cancer risk ${ }^{30}$; (3) agricultural areas, especially in Northwest Brazil, where rural workers are exposed to the sun and have a greater risk of developing lower lip cancer, especially when associated with tobacco ${ }^{17,19-23}$; (4) Southeast Brazil, where the incidence of cancer of the tongue and floor is high and strongly related to tobacco and alcohol consumption ${ }^{24-29}$. In North and Central-West regions, there is a lack of epidemiological data relating to oral cancer.

Table 2. Demographic data and predilection sites of oral cancer in Brazil.

\begin{tabular}{|c|c|c|c|c|}
\hline Authors & State & Gender & Age & Site $(\%)$ \\
\hline Coaracy et al. ${ }^{17}$ & MA & $M$ & $61-70$ & $\begin{array}{c}\text { Tongue (36.6), Lip } \\
\text { (15.5) and Floor } \\
(15.5)\end{array}$ \\
\hline Osterne et al. ${ }^{18}$ & CE & $M$ & $61-70$ & $\begin{array}{l}\text { Floor (18.0) and } \\
\text { Tongue (16.0) }\end{array}$ \\
\hline Costa et al. ${ }^{19}$ & $\mathrm{RN}$ & M & $61-70$ & $\begin{array}{c}\text { Tongue (24.6) and } \\
\text { Lip (24.1) }\end{array}$ \\
\hline Sampaio et al. ${ }^{20}$ & PB & M & $61-70$ & $\begin{array}{l}\text { Lip (25.8) and } \\
\text { Tongue (20.6) }\end{array}$ \\
\hline Barreto et al. ${ }^{21}$ & PB & $M$ & $61-70$ & $\begin{array}{c}\text { Tongue (26.1) and } \\
\text { Lip (16.5) }\end{array}$ \\
\hline Antunes et al. ${ }^{22}$ & PE & M & $61-70$ & $\begin{array}{l}\text { Tongue (29.5) and } \\
\text { Lip }(16.4)^{\star}\end{array}$ \\
\hline Anjos Hora et al. ${ }^{23}$ & SE & M & $61-70$ & $\begin{array}{c}\text { Tongue (30.6) and } \\
\text { Lip (23.5) }\end{array}$ \\
\hline Gervásio et al. ${ }^{24}$ & MG & M & $61-70$ & $\begin{array}{l}\text { Tongue (43.7) and } \\
\text { Floor (15.7) }\end{array}$ \\
\hline Daher et al. ${ }^{25}$ & MG & M & $51-70$ & $\begin{array}{l}\text { Tongue (54.4) and } \\
\text { Floor (20.8) }\end{array}$ \\
\hline Sobral et al. ${ }^{26}$ & SP & $M$ & $61-70$ & $\begin{array}{l}\text { Tongue (24.0) and } \\
\text { Floor (19.1) }\end{array}$ \\
\hline Fardin et al. ${ }^{27}$ & SP & M & $61-70$ & $\begin{array}{l}\text { Tongue (41.6) and } \\
\text { Floor (30.2) }\end{array}$ \\
\hline Perez et al. ${ }^{28}$ & SP & $M$ & $41-50$ & $\begin{array}{l}\text { Floor (24.0) and } \\
\text { Tongue (20.4) }\end{array}$ \\
\hline Oliveira et al. ${ }^{29}$ & SP & M & $51-60$ & $\begin{array}{l}\text { Tongue (28.0) and } \\
\text { Floor (27.1) }\end{array}$ \\
\hline $\begin{array}{l}\text { Guembarovstki } \\
\text { et al. }{ }^{30}\end{array}$ & PR & $M$ & $51-60$ & $\begin{array}{l}\text { Tongue (29.7) and } \\
\text { Floor (19.8) }\end{array}$ \\
\hline Pithan et al. ${ }^{32}$ & RS & M & $51-60$ & $\begin{array}{c}\text { Tongue (19.7) and } \\
\text { Palate (16.2) }\end{array}$ \\
\hline Spara et al. ${ }^{333}$ & RS & M & $51-60$ & $\begin{array}{c}\text { Tongue (38.8) and } \\
\text { Lip (33.3) }\end{array}$ \\
\hline
\end{tabular}

Note: MA: Maranhão; CE: Ceará; RN: Rio Grande do Norte; PB: Paraíba; PE: Pernambuco; SE: Sergipe; MG: Minas Gerais; SP: São Paulo; PR: Paraná; SC: Santa Catarina; RS: Rio Grande do Sul. * Data related to the Oswaldo Cruz University Hospital.

\section{FINAL CONSIDERATIONS}

We conclude that although the fight against oral cancer in Brazil is almost secular, there is still a lot to be done to combat this disease, especially in the field of primary prevention. The data suggest that the incidence of oral cancer in several regions of Brazil is still quite high, the majority of diagnosed cases occur in advanced stages of disease and care to patients remains fragmented, 
indicating a lack of oncological support services. There are variations in the epidemiological profile of patients with oral cancer in some regions of Brazil, requiring specific actions for these populations are included in prevention programs against disease.

\section{REFERENCES}

1. World Health Organization. The world health report 2004: changing history. Geneva: WHO; 2004 [cited 2010 Mar 15]. Available from: < http://www.who.int/whr/2004/en/>.

2. Petersen PE. Oral cancer prevention and control: the approach of the World Health Organization. Oral Oncol. 2009;45(4):45460. doi: 10.1016/j.oraloncology.2008.05.023.

3. Henrique PR, Bazaga Júnior M, Araújo VC, Junqueira JLC, Furuse C. Prevalência de alterações da mucosa bucal em indivíduos adultos da população de Uberaba, Minas Gerais. RGO - Rev Gaúcha Odontol. 2009;57(3):261-7.

4. Hochman G. Logo ali, no final da avenida: os sertões redefinidos pelo movimento sanitarista da Primeira República. Hist Cienc Saúde-Manguinhos. 1998;5(supl 0):217-35. doi: 10.1590/ S0104-59701998000400012.

5. Brasil. Ministério da Saúde. Secretaria de Atenção à Saúde. Instituto Nacional de Câncer. Coordenação de Prevenção e Vigilância. A situação do câncer no Brasil. Rio de Janeiro: Ministério da Saúde; 2006 [citado 2010 Mar 15]. Disponível em: <http://www.inca.gov.br/situacao/>

6. Magalhães F. A luta contra o câncer. In: $1^{\circ}$ Congresso Nacional dos Práticos - Em comemoração ao centenário da Independência do Brasil. Rio de Janeiro: Actas e Trabalhos, Fundações Científicas; 1923.

7. Kroeff M. Resenha da luta contra o câncer no Brasil: documentário do Serviço Nacional de Câncer. Rio de Janeiro: Imprensa Brasileira; 1946.

8. Brasil. Ministério da Educação e Saúde Pública. Lei n. 378 de 13 de Janeiro de 1937. Dá nova organização ao Ministério da Educação e Saúde Pública. Diário Oficial da União. Brasília (DF); 1937 jan 13 [citado 2010 Mar 15]. Disponível em: < http://legis.senado.gov.br/legislacao/ListaPublicacoes. action? id=102716>

9. Brasil. Ministério da Saúde. Instituto Nacional de Câncer. Histórias da oncologia clínica no Instituto Nacional de Câncer. Rio de Janeiro: Ministério da Saúde; 2008 [citado 2010 Mar 15]. Disponível em: < http://www1.inca.gov.br/inca/Arquivos/ publicacoes/historia_oncologia.pdf $>$.

10. Kligerman J. Fundamentos para uma política nacional de prevenção e controle do câncer. Rev Bras Cancerol. 2002;48(1):3-7.

11. Brasil. Ministério da Saúde. Secretaria Nacional de Saúde. Programa Nacional de Prevenção e Diagnóstico Precoce do Câncer Bucal - CABUL. Brasília: Ministério da Saúde; 1976.

\section{Collaborators}

PRS MARTINS FILHO and TS SANTOS participated in the literature review and writing of the article. LCF SILVA and MR PIVA was responsible for directing and writing the article.

12. Saltz E. Projeto de expansão da prevenção e controle do câncer de boca: qüinqüênio 1988-1993. Rev Bras Cancerol. 1988;34(4):221-39.

13. Teles JCB. Assistência odontológica no país: perspectivas 1 . Cad Saúde Pública. 1985;1(2):253-62. doi: 10.1590/S0102$311 \times 1985000200010$

14. Kligerman J. A ampliação da assistência oncológica no Brasil Rev Bras Cancerol. 2000;46(4):347-9.

15. Kligerman J. O papel do INCA na prevenção e controle do câncer no Brasil [editorial]. Rev Bras Cancerol. 2001;47(1):5-7.

16. Marzola C, Medani EH, Campos CRN, Toledo Filho JL, Oliveira MG Oral câncer: incidence, etiopatogeny, diagnosis, precancerous lesions, treatment and prognosis. Rev ATO. 2006;6(2):753-73.

17. Coaracy AEV, Lopes FF, Cruz MCN, Bastos EG. Correlação entre os dados clínicos e histopatológicos dos casos de carcinoma espinocelular oral do Instituto Maranhense de Oncologia Aldenora Bello, em São Luís, MA. J Bras Patol Med Lab. 2008:44(1):489-93. doi: 10.1590/S1676-24442008000100007.

18. Osterne RLV, Brito RGM, Nogueira RLM, Soares ECS, Alves APNN, Moura JFB, et al. Saúde bucal em pacientes portadores de neoplasias malignas: estudo clínico-epidemiológico e análise de necessidades odontológicas de 421 pacientes. Rev Bras Cancerol. 2008;54(3):221-6.

19. Costa ALL, Costa LJ, Souza LB, Pinto LP. Estudo retrospectivo de 952 casos de carcinoma epidermóide oral. In: $13^{\circ}$ Congresso e 26 Jornada Brasileira de Estomatologia; 2000; Brasília. Anais. Brasília: Sociedade Brasileira de Estomatologia e Patologia Bucal; 2000. p.100

20. Sampaio MCC, Birman FG, Birman EG, Novelli MD. Análise do carcinoma bucal: casuística do hospital Napoleão Laureano João Pessoa. Rev Bras Cancerol. 1985;31:125-30

21. Barreto RC, Paiva MF, Pereira GAS, Oliveira JMS. Paraíba: uma das maiores prevalências de câncer bucal da federação brasileira. Conceitos. 2001;4(6):118-22.

22. Antunes AA, Takano JH, Queiroz TC, Vidal AKL. Perfil epidemiológico do câncer no CEON/HUOC/UPE e HCP. Odontol Clin-Cientif. 2003;2(3):181-6.

23. Anjos Hora IA, Pinto LP, Souza LB, Freitas RA. Estudo epidemiológico do carcinoma epidermóide de boca no estado de Sergipe. Cienc Odontol Bras. 2003;6(2): 41-8.

24. Gervásio OLAS, Dutra RA, Tartaglia SMA, Vasconcellos WA, Barbosa AA, Aguiar MCF. Oral squamous cell carcinoma: a retrospective study of 740 cases in a brazilian population. Braz Dent J. 2001:12(1):57-61. 
25. Daher GCA, Pereira GA, Oliveira ACD. Características epidemiológicas de casos de câncer de boca registrados em hospital de Uberaba no período 1999-2003: um alerta para a necessidade de diagnóstico precoce. Rev Bras Epidemiol. 2008;11(4):584-96. doi: 10.1590/\$1415-790X2008000400007.

26. Sobral APV, Mantesso A, Souza RS, Araújo NS. Oral squamous cell carcinoma: na epidemiological study. In: $17^{\text {th }}$ International Cancer Congress; 1998; Rio de Janeiro. Anais. Rio de Janeiro: International Cancer Congress; 1998. p. 231.

27. Fardin M, Rapoport A, Amar A, Magalhães MR, Latorre MRDO. Fatores de risco no prognóstico do câncer da boca: estudo de 1440 casos. Rev Bras Cir Cabeça Pescoço. 2004;33(1):27-33.

28. Perez RS, Freitas SM, Dedivitis RA, Rapoport A, Denardin OVP, Sobrinho JA. Estudo epidemiológico do carcinoma espinocelular da boca e orofaringe. Arq Int Otorrinolaringol. 2007;11(3):271-7.

29. Oliveira LR, Ribeiro-Silva A, Zucoloto S. Perfil da incidência e da sobrevida de pacientes com carcinoma epidermóide oral um uma população brasileira. J Bras Patol Med Lab. 2006;42(5):38592. doi: 10.1590/S1676-24442006000500010

30. Guembarovski RL, Menezes RP, Poliseli F, Chaves VN, Kuasne H, Leichsenring $A$, et al. Oral carcinoma epidemiology in Paraná State, Southern Brazil. Cad Saúde Pública. 2009;25(2):393-400. doi: 10.1590/S0102-311X2009000200018.

31. Nasser N. Epidemiologia dos cânceres espinocelulares - Blumenau (SC) - Brasil, de 1980 a 1999. An Bras Dermatol. 2004;79(6):66977. doi: 10.1590/S0365-05962004000600003.
32. Pithan AS, Cherubini K, Figueiredo MAS, Yurgel LS. Perfil epidemiológico do carcinoma espinocelular de boca em pacientes do serviço de estomatologia do Hospital São Lucas da PUCRS. Rev Odonto Cienc. 2004;19(44):126-30.

33. Spara L, Spara P, Costa AG. Achados epidemiológicos de câncer da cavidade oral em hospital de referência avaliados no período de 1980-2003. Odontol Clin-Cientif. 2005;4(3):177-83.

34. Dib LL. Avaliação do nível de informação de diferentes camadas da população a respeito de aspectos relacionados ao câncer bucal [monografia]. São Paulo: Universidade Paulista; 2000.

35. Abdo EM, Garrocho AA, Aguiar MCF. Perfil do paciente portador de carcinoma epidermóide da cavidade bucal, em tratamento no Hospital Mário Penna em Belo Horizonte. Rev Bras Cancerol. 2002;48(3):357-62.

36. Hayassy A. Câncer bucal no setor público de saúde. Rev Bras Odontol. 1998;55(3):173-5.

37. Matos IB, Araújo LA. Práticas acadêmicas, cirurgiões-dentistas, população e câncer bucal. Rev ABENO. 2003;3(1):76-81.

38. Silva FD, Daniel FI, Grando LJ, Calvo MC, Rath IBS, Fabro SML. Estudo da prevalência de alterações labiais em pescadores da ilha de Santa Catarina. Rev Odonto Cienc. 2006;21(51):37-42.

Received on: 11/2/2011

Final version resubmitted on: 5/6/2011 Approved on: 24/6/201 